\title{
The Effects of Motivation, Leadership, and Work Environment on Employee's Performance: A Case of Local Government Agency in Emerging Country
}

\author{
$\underline{\text { Shantini Rumbi }}{ }^{1}$, Ferdinandus Christian ${ }^{2}$, Suparti $^{3}$ \\ 1,2,3Faculty of Economics, Universitas Terbuka, Indonesia \\ Email: shantinirumbi01@gmail.com,tamehi68@gmail.com,suparti@ecampus.ut.ac.id
}

\begin{abstract}
:
The performance of the Yapen Island Regency's Agriculture and Food Security Agency, as the responsible local government agency in developing the local agriculture sector, is still far from optimal, as seen from the decrease in its budget absorption. This study aims to determine and analyze the influences of work motivation, leadership, and work environment on employee performance at the mentioned local government agency. This quantitative research used a survey employing a questionnaire as a research instrument. Of 108 public officers became the sample. Multiple regression tests analyzed data with the help of SPSS software. The results showed that 1) there was a significant influence of motivation on employee performance, 2) there was a significant effect of leadership on employee performance, 3) there was a significant effect of the work environment on employee performance, and 4) motivation was the most dominant factor in affecting employee performance at the observed local government agency.
\end{abstract}

Keywords: work motivation; leadership; work environment; employee performance

\section{Introduction}

An organization requires human resources (HR) as the primary driving force of activities related to the company (Chadwick \& Dabu, 2009). HR is the most critical factor of the company because it helps the company achieve its targeted outcome and goals (Wirtenberg et al., 2007). Therefore, every organization, including government organizations, always tries to improve the performance of its employees, namely the state civil apparatus, to improve the performance of these government organizations (Fernandez \& Moldogaziev, 2013).

The primary tasks of government officials as state civil apparatus and civil servants are to administer the government offices and provide services to the community, which serve as the benchmarks for their performance (Tarandung, 2016). The service performance of the Yapen Islands Regency's Agriculture and Food Security Agency can be seen from several indicators, one of which is the budget and expenditure realization. The budget and expenditure realization of the observed local government agency presented in Table 1 marks a decreasing trend in the percentage of budget realization from 2013 to 2017 . The percentage experienced a jump in 2015, only to drop again in 2016 and 2017. 
Table 1. Budget and Budget Realization for 2013-2017

\begin{tabular}{|c|r|r|c|}
\hline \multicolumn{1}{|c|}{ Year } & Budget & Realization & $\begin{array}{c}\text { Budget Realization } \\
\text { Percentage }\end{array}$ \\
\hline 2013 & Rp1.351.718.000 & Rp1.351.718.000 & $100,00 \%$ \\
\hline 2014 & Rp1.923.320.000 & Rp1.890.779.164 & $96,47 \%$ \\
\hline 2015 & Rp17.875.347.000 & Rp17.574.592.000 & $98,31 \%$ \\
\hline 2016 & Rp21.786.528.000 & Rp21.254.967.000 & $97,56 \%$ \\
\hline 2017 & Rp24.931.147.857 & Rp24.092.966.147 & $96,64 \%$ \\
\hline
\end{tabular}

Source: The Yapen Islands Regency's Agriculture and Food Security Agency (2019)

The budget realization of the observed local government agency for 2013-2017 indicated an efficient use of budget allocation because no budget realization exceeds the predetermined budget amount. However, at the same time, the budget realization also denoted a declining trend in budget absorption. Inefficient budget absorption implies problems in budget management, such as poor program and activity planning, poor coordination between planning units and activity implementation units, and poorly implemented programs (Fahrianta \& Carolina, 2016). The decrease in the absorption capacity of the annual budget also indicates the low performance of the observed local government agency. The allocated budget should be best utilized to improve performance. The performance of its public officers also determines the performance of the observed local government agency.

Many factors contribute to employee performance. There have been countless researches on Indonesia public officers' performance. These researches found that the following factors can affect government agencies' performance, especially those related to the observed local government agency. These factors are competence (Syamsir \& Ramlawati, 2019), motivation (Syamsir \& Ramlawati, 2019; Sulaeman, 2018; Indrawati, 2019), organizational culture (Indrawati, 2019), leadership (Syamsir \& Ramlawati, 2019; Sakti et al., 2018), work environment (Tandoapu et al., 2020), job satisfaction (Tandoapu et al., 2020), employee discipline in the workplace (Sulaeman, 2018; Sakti et al., 2018), and compensation (Sakti et al., 2018; Saleleng \& Soegoto, 2015).

This research used the factors found to affect the employee performance at the observed local government agency by the prior studies as a reference for conducting an initial survey. The initial survey was undertaken by distributing questionnaires to 33 employees at the studied organization to determine the influential factors that affected employee performance. The results of the initial survey showed three factors that were mostly selected by respondents, namely motivation (90.1\%), leadership (84.85\%), and work environment $(75.76 \%)$. Based on the initial survey, this study focused on examining the extent of these three factors affecting employee performance at the observed local government agency.

Many theories have proven how motivation can improve employee performance (Kuranchie-Mensah \& Amponsah-Tawiah, 2016). According to Maduka and Okafor (2014), motivation refers to the willingness of an individual to put more significant efforts to attain particular goals. Knowing what employees need can help companies motivate these employees, thereby improving their performance (Uzonna, 2013; Warokka et al., 2012). Efendi et al. (2019) added that work motivation is the impetus for companies to improve the performance of their employees. 
Field observations denoted that employees of the observed local government organization were low motivated, as indicated by the high percentage of employee lateness to show up for work or tardiness in completing their job according to the predetermined schedule. Low motivation can impact the low performance of employees (Wolf \& Smith, 1995). Therefore, this study aims to analyze motivational factors as the main factor that affects employee performance. Employee performance is inseparable from the leadership qualities in an organization (Alfanny, 2018). Sharma and Jain (2013) defined leadership as a process whereby an individual influences others to accomplish an objective and directs them in a way that makes them more cohesive and coherent. Successful leaders can move their subordinates to achieve high performance (Guterresa et al., 2020). Furthermore, the work environment is another essential factor affecting employee performance (Imran et al., 2012). According to Fatihudin (2018), the work environment is everything that surrounds an employee at work and has an impact on the employee.

The main problem in the work environment of the studied local government organization is inadequate facilities and infrastructure even though facilities and infrastructure are an essential part of carrying out activities at the observed organization. The data from the Strategic Plan of the observed local government organization for 2019-2020 recorded several damaged facilities and infrastructure. Of the 16 buildings, seven buildings were damaged, namely the BPP Indanda office, a greenhouse, an extension post building, the regional level officer's (Mantri Tani) house, a Warari cattle park, a Kamanap livestock park, and a farmhouse in Ambaidiru. In addition to the ruined buildings, there are also damaged two-wheeled plantation vehicles, speed boats, and slide-projector. The damage to some of these facilities and infrastructure can result in poor employee performance.

Various empirical studies revealed mixed findings, which led to research gaps. Some researchers found that motivation positively affects employee performance (Guterresa et al., 2020; Kuswati, 2020), but other studies stated the opposite (Muchtar, 2016). Some researchers also denoted a positive effect of leadership on employee performance (Guterresa et al., 2020), but other studies could not prove the positive effect (Darojat et al., 2019). Likewise, with the results of research on the effect of the work environment on employee performance. Some researchers found a positive and significant effect (Muchtar, 2016), while other researchers did not significantly affect (Akbar, 2017). These inconsistent findings created a research gap to be further reviewed in this study using a different model. Given the above description, the researchers aim to examine the motivational factors, leadership style, and work environment that affect the observed local government agency's public officers to improve their service performance.

\section{Review of Literatures}

\subsection{Employee Performance}

Human resources in the 21 st century are considered vital assets for any company in achieving its goals (Hafiza et al., 2011). Munawaroh et al. (2013) added that human resources having good performance are assets for organizations because they impact improving the quality of organizations, especially government organizations that prioritize service aspects. At the government level, human resources, commonly referred to as state civil apparatus (ASN Aparatur Sipil Negara), can administer government and community services, which are used as benchmarks for assessing their work performance (Tarandung, 2016). Chunghtai (2008) further added that one of the potentials to be taken into account and the main factor in ensuring the government's objective in developing the country is the performance of the state civil apparatus. 
According to Martono et al. (2018), performance indicates what the employees have done. Meanwhile, employee performance denotes an individual's ability to perform and complete a task to help the organization achieve its goals. For this reason, it is imperative to conduct an objective performance assessment to assist the leader in improving the employee's performance (Pananrangi et al., 2020).

\subsection{Motivation}

The word 'motivation' is derived from the Latin' movere,' which means to move (Ramlall, 2008). Motivation is the key to the success of an organization to maintain efficient work continuity and help the organization survive (Omolo, 2015). Jurkiewicz et al. (1998), in their research, found that highly motivated employees will reduce the rate of work accidents, the level of ethical problems, increase attendance, and reduce employee turnover rates. Motivation is the process of giving motives, encouragement, or stimulation to subordinates so that they want to work consciously and sincerely as well as have passion in the effort to achieve organizational goals. To motivate employees or subordinates, the organization leadership must know the motives and motivations desired by the employees. There are many kinds of motivations such as giving proper and fair compensation, giving awards, and so on. (Kuswati, Y. 2019)

According to Kuranchie-Mensah and Amponsah-Tawiah (2016), employee motivation is a sensitive matter, so steps are needed to determine good motivation to assist employees in achieving their performance. Several previous researchers have proven a positive and significant effect of motivation on employee performance (Kuswati, 2020). Therefore, based on previous empirical findings, this study proposes the first hypothesis as follows:

H1: Motivation significantly affects the employee performance

\subsection{Leadership Style}

Leadership in an organization is critical in creating a vision, mission, setting goals, designing strategies, policies and methods used to achieve organizational goals effectively and efficiently, and directing and coordinating organizational efforts and activities (Xu \& Wang, 2008). Leaders must know which leadership styles can influence the employees and lead to positive or negative impacts (Sethuraman \& Suresh, 2014). Problem-solving and decisionmaking skills are the required qualities for a leader (Hersona and Sidharta, 2017). Combining the appropriate leadership style will enable a leader to improve the innovative and creative ability of employees, which in turn improves employee performance (Guterresa et al., 2020). This finding is in line with previous empirical findings, which found a significant positive relationship between leadership and employee performance (Hersona \& Sidharta, 2017). Therefore, based on the theory and previous empirical findings, this study proposes the second hypothesis as follows:

H2: Leadership influences employee performance significantly

\subsection{Work Environment}

The work environment is a physical and behavioral component that can positively or negatively impact employee behavior and performance (Olson \& Borman, 1989). According to Nasution (2013), the work environment is something around the organization that can affect the activities and productivity of employees. Previous research has proven a positive and significant effect of the work environment on employee performance (Muchtar, 2016; Wahyudi et al., 2020). In addition, good workplace conditions will create a comfortable working atmosphere for employees and boost work performance (Putra \& Putri, 2020). Therefore, referring to the previous empirical findings, this study proposes the third hypothesis as follows: 
H3: The work environment affects employee performance

\subsection{Analysis of the Power Size Effect}

The organization's success is also highly dependent on the motivation of its employees (Osabiya, 2015). Technically, the elements that enable employees to carry out their respective responsibilities and activities are also influenced by work teams and groups, leadership, and management (McMurray et al., 2012). Several previous researchers have examined the effect of motivation, leadership, and work environment on employee performance (Darojat et al., 2019; Muchtar, 2016), but there were only a few to examine the power size effect of each independent variable on employee performance. Therefore, this study further develops the previous research by examining the power size effect of work motivation variables and work environment on employee performance with the following proposed propositions:

P1: There is a different power size effect of each variable (work motivation, leadership, and work environment) on employee performance

Based on the theory mentioned above, which is supported by several relevant previous studies, this study will analyze the influences of work motivation, leadership, and work environment on employee performance at the studied local government agency. The conceptual framework in this study can be described as follows.

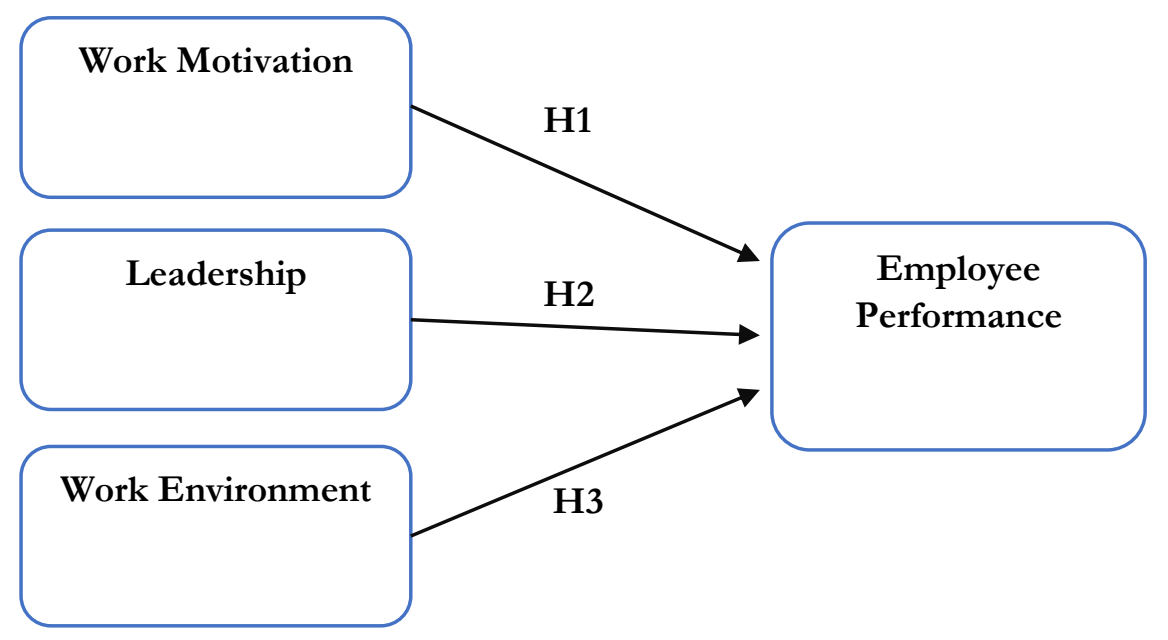

\section{Research Methods}

This research used a quantitative method and is classified as causality or explanatory research. According to Creswell (2013), quantitative research tests a theory by studying the relationship between variables. The causal study design was utilized to determine the causal relationship of the variables in the study (Santoso \& Tjiptono, 2002). The data were obtained through a survey by distributing questionnaires as a compiled-research instrument with a 5point Likert scale.

The research population included all employees at the studied local government organization, totaling 108 employees. Given the small size of the research population, this study used a saturated sampling method by involving the entire population as the research sample. SPSS statistical program was used to analyze the data. The data were then analyzed with descriptive analysis. It applied validity and reliability testing, classical assumption test, and regression analysis to determine the effect of independent variables (i.e., motivation, leadership, and work environment) on the dependent variable, namely employee performance. 


\section{Results and Discussion}

Respondents, who participated in a particular study, were asked to answer the questions either through interviews or questionnaires (Saunders et al., 2011). The characteristics of the respondents proceeded for further analysis related to the collected data. In this study, the characteristics of the respondents were analyzed based on gender, age, length of work, and education. The results of the descriptive analysis in Table 2 represents that most of the respondents were male $(56.50 \%)$, aged $41-50$ years $(45.40 \%)$, with an undergraduate education level $(76.90 \%)$, working in the studied local government agency for $6-10$ years $(62 \%)$.

Table 2. Descriptive Characteristics of Respondents

\begin{tabular}{cccc}
\hline Category & Alternative Answer & Number of Respondents & Percentage (\%) \\
\hline \multirow{2}{*}{ Sex } & Male & 61 & $56,50 \%$ \\
& Female & 47 & $43,50 \%$ \\
\hline \multirow{2}{*}{ Age } & $20-30$ year old & 8 & $7,40 \%$ \\
& $31-40$ year old & 17 & $15,70 \%$ \\
& $41-50$ year old & 49 & $45,40 \%$ \\
& $>50$ yeard old & 34 & $31,50 \%$ \\
\hline \multirow{2}{*}{ Period of Service } & $<5$ years & 18 & $16,70 \%$ \\
& $6-10$ years & 67 & $62,00 \%$ \\
& $>10$ years & 23 & $21,30 \%$ \\
\hline \multirow{3}{*}{ Educational } & High School & 4 & $3,70 \%$ \\
Background & Diploma 3 & 6 & $5,60 \%$ \\
& Bachelor Degree & 83 & $76,90 \%$ \\
& Master Degree & 15 & $13,90 \%$ \\
\hline
\end{tabular}

The respondents' responses related to motivation, leadership, work environment and employee performance were classified with an interval scale ranging from the highest to the lowest score divided by five, thus obtaining an interval of 0.80 . With an interval of 0.80 , the categorization system is as follows: 1.00-1.80 (very low); 1.81-2.60 (low); 2.61-3.40 (moderate); 3,41-4.20 (high); and 4.21-5.00 (very high). From the average of respondents' responses (Table 3 ), the mean scores of the motivation, leadership, work environment, and employee performance variables are $3.93,4.15,4.03$, and 4.04 , which are in the high category. These results indicate that the studied local government agency's motivation, leadership style, and work environment are good and are expected to affect employee performance significantly.

Table 3. Distribution of Respondents' Responses

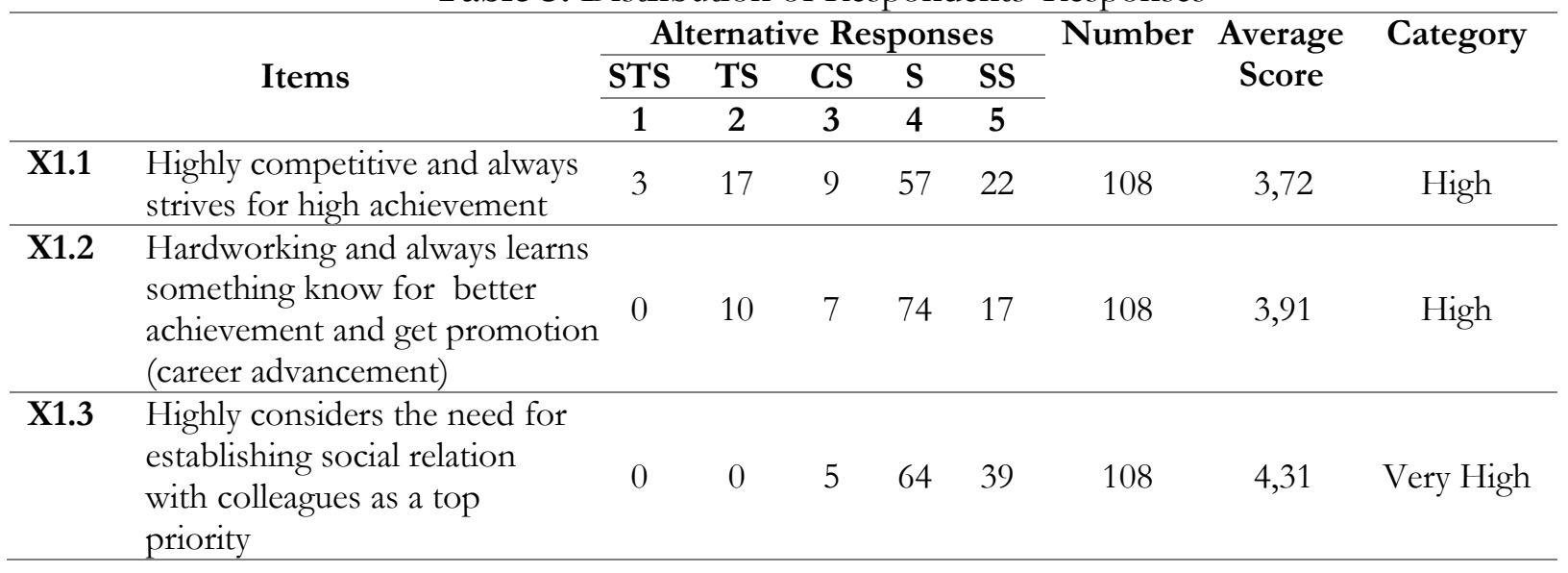




\begin{tabular}{|c|c|c|c|c|c|c|c|c|c|}
\hline $\mathrm{X} 1.4$ & $\begin{array}{l}\text { Highly considers the need for } \\
\text { mutual openness and good } \\
\text { communication with } \\
\text { coworkers, relations, and } \\
\text { managers as a top priority }\end{array}$ & 0 & 0 & 7 & 68 & 33 & 108 & 3,24 & Moderate \\
\hline $\mathrm{X} 1.5$ & $\begin{array}{l}\text { Maintaining high performance } \\
\text { by expecting recognition from } \\
\text { colleagues and managers to } \\
\text { inspire others at work }\end{array}$ & 3 & 11 & 27 & 57 & 10 & 108 & 3,56 & High \\
\hline $\mathrm{X} 1.6$ & $\begin{array}{l}\text { Responsible and eager for } \\
\text { having a competitive challenge }\end{array}$ & 0 & 12 & 10 & 68 & 18 & 108 & 3,85 & High \\
\hline \multicolumn{8}{|c|}{ Average } & 3,93 & High \\
\hline $\mathrm{X} 2.1$ & $\begin{array}{l}\text { Leaders are able to serve as } \\
\text { role models for employees }\end{array}$ & 0 & 0 & 17 & 42 & 49 & 108 & 4,30 & Very High \\
\hline $\mathrm{X} 2.2$ & $\begin{array}{l}\text { Leaders have extensive } \\
\text { knowledge in completing tasks } \\
\text { and can help employees by } \\
\text { providing guidelines on work } \\
\text { completion work to enable a } \\
\text { clear target achievement. }\end{array}$ & 0 & 0 & 24 & 46 & 38 & 108 & 4,13 & High \\
\hline $\mathrm{X} 2.3$ & $\begin{array}{l}\text { Leaders direct employees to } \\
\text { achieve organizational goals } \\
\text { through predetermined targets } \\
\text { in the work program }\end{array}$ & 0 & 7 & 22 & 42 & 37 & 108 & 4,01 & High \\
\hline $\mathrm{X} 2.4$ & $\begin{array}{l}\text { Leaders direct and develop } \\
\text { employees to stimulate new } \\
\text { ideas and opinions }\end{array}$ & 0 & 5 & 13 & 47 & 43 & 108 & 4,19 & High \\
\hline $\mathrm{X} 2.5$ & $\begin{array}{l}\text { Leaders know and understand } \\
\text { the needs of their employees }\end{array}$ & 0 & 3 & 17 & 52 & 36 & 108 & 4,12 & High \\
\hline \multicolumn{8}{|c|}{ Average } & 4,15 & High \\
\hline $\mathrm{X} 3.1$ & $\begin{array}{l}\text { The workplace has adequate } \\
\text { lighting to provide safe } \\
\text { working environment for } \\
\text { smooth workflow }\end{array}$ & 0 & 6 & 14 & 64 & 24 & 108 & 3,98 & High \\
\hline $\mathrm{X} 3.2$ & $\begin{array}{l}\text { The workplace has a good air } \\
\text { circulation to provide } \\
\text { adequate fresh air }\end{array}$ & 0 & 2 & 15 & 61 & 30 & 108 & 4,10 & High \\
\hline X3.3 & $\begin{array}{l}\text { The work environment is noise- } \\
\text { free to enable smooth workflow } \\
\text { without any disruption }\end{array}$ & 0 & 10 & 18 & 69 & 11 & 108 & 3,75 & High \\
\hline X3.4 & $\begin{array}{l}\text { The safety of the work } \\
\text { environment is guaranteed to } \\
\text { allow workers to work at ease }\end{array}$ & 0 & 2 & 8 & 62 & 36 & 108 & 4,22 & Very High \\
\hline X3.5 & $\begin{array}{l}\text { The work environment is very } \\
\text { pleasant and the colleagues } \\
\text { and managers establish a very } \\
\text { harmonious relationship }\end{array}$ & 0 & 1 & 12 & 78 & 17 & 108 & 4,03 & High \\
\hline X3.6 & $\begin{array}{l}\text { The work environment is very } \\
\text { pleasant because it is supported } \\
\text { by adequate facilities and } \\
\text { infrastructure to support } \\
\text { employee performance }\end{array}$ & 0 & 2 & 23 & 44 & 39 & 108 & 4,11 & High \\
\hline \multicolumn{8}{|c|}{ Average } & 4,03 & High \\
\hline Y.1 & $\begin{array}{l}\text { Have a high performance and } \\
\text { provide a good and }\end{array}$ & 0 & 0 & 5 & 40 & 63 & 108 & 4,54 & Very High \\
\hline
\end{tabular}




\begin{tabular}{lllllllllll}
\hline Y.2 & $\begin{array}{l}\text { appropriate result } \\
\begin{array}{l}\text { Carry out a large number of } \\
\text { jobs appropriately based on } \\
\text { the predetermined timeline }\end{array}\end{array}$ & 0 & 2 & 34 & 59 & 13 & 108 & 3,77 & High \\
\hline Y.3 & $\begin{array}{l}\text { Carry out jobs appropriately } \\
\text { according to schedule. }\end{array}$ & 0 & 5 & 14 & 57 & 32 & 108 & 4,07 & High \\
\hline Y.4 & $\begin{array}{l}\text { Carry out jobs effectively } \\
\text { Y.5 }\end{array}$ & $\begin{array}{l}\text { Carry out jobs quickly and } \\
\text { appropriately without any } \\
\text { supervision from managers }\end{array}$ & 5 & 14 & 22 & 50 & 17 & 108 & 3,56 & High \\
\hline Y.6 & $\begin{array}{l}\text { Able to work well in team } \\
\text { with coworkers }\end{array}$ & 0 & 0 & 8 & 78 & 22 & 108 & 4,13 & High \\
\hline & Average & & & & & & & & & \\
\hline
\end{tabular}

Notes: STS = Very Disagree; TS = Disagree; CS = Fairly Agree; $\mathrm{S}=$ Agree; SS = Very Agree, $\mathrm{X} 1$ = Motivation; X2 = Leadership; X3 =Work Environment; Y = Employee Performance.

Before testing the hypothesis, the data were firstly tested for the level of validity and reliability. Validity testing was undertaken to determine whether the research instrument used was following the research object under study. Meanwhile, reliability testing was done to measure the consistency of the research instrument. The validity test results indicate that all statements (items) in all research variables have a statistical r-value greater than the r-table, namely 0.1591. Therefore, all statements are declared valid. The value of Cronbach's Alpha indicated the results of reliability testing. Based on Table 4, all variables, namely work motivation, leadership, work environment, and employee performance, have Cronbach's Alpha values of $>0.70$. Therefore, all statements on the variables are declared reliable and can be used to examine data under the same conditions and trustworthy.

Table 4. Validity and Reliability Test Results

\begin{tabular}{lcc}
\hline Items & R Statistic & Cronbach's Alpha \\
\hline X1.1 & 0,806 & \\
X1.2 & 0,763 & 0,772 \\
X1.3 & 0,583 & \\
X1.4 & 0,497 & \\
X1.5 & 0,703 & \\
X1.6 & 0,725 & \\
\hline X2.1 & 0,843 & 0,868 \\
X2.2 & 0,799 & \\
X2.3 & 0,853 & \\
X2.4 & 0,763 & \\
X2.5 & 0,796 & 0,787 \\
\hline X3.1 & 0,709 & \\
X3.2 & 0,773 & \\
X3.3 & 0,579 & \\
X3.4 & 0,769 & \\
X3.5 & 0,661 & \\
X3.6 & 0,718 & \\
\hline Y.1 & 0,706 & \\
Y.2 & 0,612 & \\
Y.3 & 0,663 & \\
Y.4 & 0,750 & \\
Y.5 & 0,494 & \\
Y.6 & 0,703 & \\
\hline
\end{tabular}


Afterwards, the researchers tested the classical assumption by conducting a normality test, multicollinearity test, and heteroscedasticity test. Researchers conducted a normality test to find out whether the data obtained were normally distributed or not. Normality test was carried out using the Kolmogorov Smirnov test. The results of the normality test (Table 5) indicate that the Asymp value. Sig of 0.058 is more significant than 0.05 . This result means that the data is normally distributed.

The steps continued with a multicollinearity test to determine whether the regression model is correlated with the independent variables. A correlation indicates a multicollinearity problem. The test results (Table 5) showed that the independent variables, namely work for motivation, leadership, and work environment, have tolerance values greater than 0.10 and VIF values less than 10 . Thus, it can be concluded that there is no multicollinearity in the regression model.

The last stage of the classic assumption test was the heteroscedasticity test to determine whether there is an error or inequality of variance from the residual of observation to another observation in the regression model. Researchers used the Glejser test to find out the results. It showed that the significant value of the three variables used was more than 0.05 . This result means that there is no heteroscedasticity problem in the regression model used by the researcher.

Table 5. Classical Assumption Test Results

\begin{tabular}{ccccccc}
\hline \multirow{2}{*}{ Normality Test } & \multicolumn{3}{c}{ Multicollinearity Test } & \multicolumn{2}{c}{$\begin{array}{c}\text { Hetoscedasticity } \\
\text { Test }\end{array}$} \\
\hline \multirow{2}{*}{$\begin{array}{c}\text { Kolmogorov } \\
\text { Smirnov }\end{array}$} & $\begin{array}{c}\text { Asymp. } \\
\text { Sig }\end{array}$ & Variable & Tolerance & VIF & Sig Score & $\begin{array}{c}\text { Sig } \\
\text { Limit }\end{array}$ \\
\cline { 3 - 7 } & & $\mathrm{X} 1$ & 0,802 & 1,247 & 0,383 & 0,05 \\
\hline \multirow{2}{*}{0,084} & 0,058 & $\mathrm{X} 2$ & 0,713 & 1,402 & 0,080 & 0,05 \\
\cline { 3 - 7 } & & $\mathrm{X} 3$ & 0,681 & 1,468 & 0,074 & 0,05 \\
\hline
\end{tabular}

Table 6. Results of Multiple Regression Analysis and Hypothesis Testing

\begin{tabular}{|c|c|c|c|c|c|c|}
\hline \multirow{2}{*}{\multicolumn{2}{|c|}{ Model }} & \multicolumn{2}{|c|}{ Unstandardized Coefficients } & \multicolumn{2}{|l|}{$\begin{array}{c}\text { Standardized } \\
\text { Coefficients }\end{array}$} & \multirow[b]{2}{*}{ Sig. } \\
\hline & & B & Std. Error & Beta & $\mathrm{t}$ & \\
\hline 1 & (Constant) & 9,284 & 3,514 & & 4,574 & 0,000 \\
\hline & Work Motivation & 0,213 & 0,073 & 0,256 & 2,899 & 0,005 \\
\hline & Leadership Style & 0,213 & 0,079 & 0,252 & 2,693 & 0,008 \\
\hline & Work Environment & 0,227 & 0,088 & 0,247 & 2,583 & 0,011 \\
\hline & R Square & 0,351 & & & & \\
\hline
\end{tabular}

a. Dependent Variable: Employee Performance

Based on the multiple linear regression test, it is proven that work motivation has a significant effect on employee performance and supports the first hypothesis. This finding can be seen from the t-statistical value of 2.899 and a significance of $0.005<0.05$. These results mean that the better the employee's motivation, the higher the employee's performance. The findings of this study are in line with previous research, which found a positive and significant relationship between motivation and employee performance (Guterresa et al., 2020; Kuswati, 2020). 
Employees at the observed local government organization are motivated mainly by the need for affiliation. Based on McClelland's (1961) work motivation theory, the need for affiliation is the need for a warm, friendly, and loving relationship. Employees feel that establishing social ties with co-workers and other people and being open to each other, and establishing good communication between co-workers and managers is very important. When the needs of these affiliates are met, they will be motivated to work better, which ultimately improves their performance.

Subsequent hypothesis testing shows that leadership has a positive and significant effect on employee performance and supports the second hypothesis. These results can be proven from the t-statistical value of 2.693 and a significance value of $0.008<0.05$. The better the leadership applied at the studied local government agency, the better the employee performance will be. This finding is in line with previous researchers who also found a positive and significant impact of leadership on employee performance (Guterresa et al., 2020).

Leaders in the studied local government organization are ideal figures who provide expected guidance by serving as role models for their employees. In addition, leaders can also provide intellectual stimulation to spark employee ideas and opinions required for solving problems. The results of this study support the leadership theory proposed by Bass and Avolio (1994), who suggested four dimensions of leadership: leaders who provide ideal influence, inspirational leaders, intellectually stimulating leaders, and leaders who pay personal attention to each employee.

The results of the third hypothesis testing obtained a statistical $t$ value of 2.583 and a significance value of $0.011<0.05$, which means that there is a positive and significant effect of the work environment on employee performance. Thus, this study supports the third hypothesis. These results align with previous researchers who also found a positive and significant effect of the work environment on employee performance (Muchtar, 2016; Wahyudi et al., 2020). The better and more conducive the work environment at the studied local government agency, the better the performance of the employees there. The work environment at the observed local government organization is proven to affect employee performance. Employees can improve their performance because they are supported by a safe work environment and adequate facilities and infrastructure to work at ease.

Based on the standardized coefficients beta values resulted from the multiple linear regression analysis, it can be seen that the work motivation variable has the most considerable coefficient value of 0.256 . It means that motivation is the most influencing factor on employee performance compared to the standardized coefficients beta value of leadership and work environment variables. Thus, it can be concluded that motivation is the most dominant factor influencing employee performance at the studied local government agency. Thus, the proposition of this study, "There is a different power size effect of each variable (i.e., work motivation, leadership, and work environment) on employee performance at the examined local government agency," is proven. Work motivation enables the employees to have a high work enthusiasm and helps them achieve specific goals (Saleleng \& Soegoto, 2015).

Finally, the researchers conducted the $\mathrm{R}^{2}$ test (coefficient of determination) to measure motivation, leadership style, and work environment in explaining the performance of employees at the observed local government agency. The results of the calculation of the coefficient of determination obtained the value of $\mathrm{R}^{2}=0.351$, which means that $35.1 \%$ of employee performance can be explained by the variables of motivation, leadership, and work environment. In comparison, the remaining $64.9 \%$ is influenced or explained by other variables not included in this study. 


\section{Conclusion}

Based on the results of research on the effect of work motivation, leadership, and work environment on employee performance at the Yapen Islands Regency's Agriculture and Food Security Agency, the following conclusions can be drawn: (1) Work motivation affect employee performance; (2) Leadership affect employee performance; (3) Work environment affect the performance of employees. This finding means that the higher the work motivation, leadership, and environment of employees, the better the performance of employees. In addition, motivation is the most dominant factor to influence employee performance.

However, this study has several limitations. First, the data obtained in this study were only derived from questionnaire distribution. This study was very dependent on the respondents' interpretation in answering the questionnaire, which might lead to bias. Second, the variables studied in this study were only a few and were deemed insufficient to measure the overall performance of employees at the studied local government agency. Third, the number of samples was considered small so that the research results are not necessarily relevant to the object of research with a larger population.

Based on the results of the study's discussion, conclusions, and limitations, the researcher provides suggestions for leaders at the Yapen Islands Regency's Agriculture and Food Security Agency to pay attention to the needs that motivate employees to improve their performance. Leaders can provide sufficient space for employees to interact with co-workers, involve them in teamwork, and provide recognition, appreciation, and promotion opportunities for employees.

In terms of leadership, leaders in the studied local government agency should motivate and guide their employees to achieve the predetermined targets and goals. They also should improve the quality of leadership to become good role models for employees, encourage employees to propose creative and innovative ideas/opinion, and pay more personal attention and care to the needs of employees. In terms of the work environment, leaders at the examined local government organization must overcome the noise problem in the workplace by finding noise sources and applying sound suppression technology or improving the spatial layout and good room dividers. It is also suggested that further researchers add mediating and moderating variables because direct influence research has been widely studied. Then, further researchers can also use supporting data, such as interviews, to obtain the result with better accuracy by avoiding bias tendency.

\section{References}

Akbar, M. (2017). The Influence Of Leadership And Work Environment On Employee Performance: A case Study Of A Private University In Jakarta. European Journal of Research and Reflection in Educational Sciences Vol, 5(1), 85.

Alfanny, J. (2018). Analysis of Leadership Style on Performance (Case Study Employee of Directorate of Infrastructure Investment Development, Ministry of Public Works and Housing). JURNAL SOSIAL HUMANIORA (JSH), 11(1), 19-26.

Chadwick, C., \& Dabu, A. (2009). Human resources, human resource management, and the competitive advantage of firms: Toward a more comprehensive model of causal linkages. Organization science, 20(1), 253-272.

Chunghtai, A. A. (2008). Impact of Job Involvement on In-Role Job Performance and Organizational Citizenship Behaviour. Institute of Behavioral and Applied Management, 169-183. 
Creswell, J. W. (2013). Research Design: Pendekatan Kualitatif, Kuantitatif, dan Mixed. Yogyakarta: Pustaka Pelajar.

Darojat, T. A., Rahmat, A., \& Djaafar, L. (2019). The Effect of Work Discipline, Work Motivation and Leadership on Employee Performance at PT. Devrindo Widya Karawang - Indonesia. International Journal of Engineering and Advanced Technology (IJEAT), 9(1), 627-630.

De Jong, J. P. J., \& Den Hartog, D. N. (2007). How leaders influence employees' innovative behaviour. European Journal of Innovation Management, 10(1), 41-64. https://doi.org/10.1108/14601060710720546

Efendi, R., \& Indartono, S. (2019). The Mediation of Economic Literacy on the Effect of Self Control on Impulsive Buying Behaviour Moderated by Peers. International Journal of Economics and Financial, 9(3), 98-104.

Fahrianta, R. Y., \& Carolina, V. (2016). Analisis Efisiensi Anggaran Belanja Dinas Pendidikan Kabupaten Kapuas. Jurnal Manajemen dan Akuntansi, 13(1).

Fatihudin, D. (2018). The Effect of Work Environment on Employee Performance Through the Job Satisfaction in Drinking Water Company Pandaan Indonesia. International Journal of Management and Economics Invention, 4(11), 1982-1988. https://doi.org/10.31142/ijmei/v4i11.0

Fernandez, S., \& Moldogaziev, T. (2013). Using employee empowerment to encourage innovative behavior in the public sector. Journal of public administration research and theory, 23(1), 155-187.

Guterresa, L., Armanu, A., \& Rofiaty, R. (2020). The role of work motivation as a mediator on the influence of education-training and leadership style on employee performance. Management Science Letters, 10(7), 1497-1504.

Hafiza, N. S., Shah, S. S., \& Jamsheed, H. (2011). Relationship between Rewards and Employee's Motivation in the Non-Profit Organizations of Pakistan. Business Intelligence Journal, 4(12), 327-334.

Hersona, S., \& Sidharta, I. (2017). INFLUENCE OF LEADERSHIP FUNCTION, MOTIVATION AND WORK DISCIPLINE ON EMPLOYEES'PERFORMANCE. Jurnal Aplikasi Manajemen, 15(3), 528-537.

Imran, R., Fatima, A., \& Zaheer, A. (2012). How to Boost Employee Performance: Investigating the Influence of Transformational Leadership and Work Environment in a Pakistani Perspective How to Boost Employee Performance: Investigating the Influence of Transformational Leadership and Work Environm. Middle-East Journal of Scientific Research, 11(10), 1455-1462. https://doi.org/10.5829/idosi.mejsr.2012.11.10.741

Indrawati, L. (2019). Pengaruh Budaya Organisasi dan Motivasi Kerja terhadap Kinerja Pegawai pada Dinas Pertanian Tanaman Pangan dan Hortikultura Kabupaten Lampung Tengah. JURNAL SIMPLEX, 2(2), 90-97.

Jurkiewicz, C. L., Massey, T. K., \& Brown, R. G. (1998). Motivation in Public and Private Organizations. Public Productivity \& Management Review, 21(3), 230-250.

Kuranchie-Mensah, E. B., \& Amponsah-Tawiah, K. (2016). Employee motivation and work performance: A comparative study of mining companies in Ghana. Journal of Industrial Engineering and Management (JIEM), 9(2), 255-309.

Kuswati, Y. (2020). The Effect of Motivation on Employee Performance. Budapest International Research and Critics Institute (BIRCI-Journal): Humanities and Social Sciences, 3(2), 995-1002. https://doi.org/10.33258/birci.v3i2.928

Kuswati, Y. (2019). Motivation Role in Improving Work Effectiveness. Budapest International Research and Critics Institute-Journal (BIRCI-Journal). P. 281-288 
Maduka, C. E., \& Okafor, O. (2014). Effect of Motivation on Employee Productivity: A Study of Manufacturing Companies in Nnewi. International Journal of Managerial Studies and Research, 2(7), 137-147.

Martono, S., Khoiruddin, M., \& Wulansari, N. A. (2018). Remuneration Reward Management System As a. International Journal of Business \& Society, 19(4), 535-545.

McClelland, D. (1961). The Achieving Society. Princeton NJ: Van Nostrand.

McMurray, A. J., Islam, M., Sarros, J. C., \& Pirola-Merlo, A. (2012). The impact of leadership on workgroup climate and performance in a non-profit organization. Leadership \& Organization Development Journal, 33(6), 522-549. https://doi.org/10.1108/01437731211253000

Muchtar, M. (2016). The influence of motivation and work environment on the performance of employees. Sinergi: Jurnal Ilmiah Ilmu Manajemen, 6(2), 27-40.

Munawaroh, A., Riantoputra, C. D. S., \& Marpaung, S. B. (2013). Factors Influencing Individual Performance In An Indonesian Government Office. The South East Asian Journal of Management, 7(2), 51-60. https://doi.org/10.21002/seam.v7i2.2051

Nasution, W. A. (2013). Pengaruh Kompensasi dan Lingkungan Kerja Terhadap Kepuasan Kerja Karyawan Pada Pt. Karya Deli Stelindo Medan. Jurnal Manajemen Bisnis Stie Ibbi, 20(2), 1-9.

Olson, D. M., \& Borman, W. C. (1989). More Evidence on Relationships Between the Work Environment and Job Performance. Human Performance, 2(2), 113-130. https://doi.org/10.1207/s15327043hup0202_3

Omolo, P. A. (2015). Effect of motivation on employee performance of commercial banks in Kenya: A case study of Kenya Commercial Bank in Migori County. International Journal of Human Resource Studies, 5(2), 87. https://doi.org/10.5296/ijhrs.v5i2.7504

Osabiya, B. J. (2015). The effect of employees motivation on organizational performance. Journal of public administration and policy research, 7(4), 62-75. https://doi.org/10.5897/JPAPR2014.0300

Pananrangi, M., Lewangka, O., \& Sudirman, I. (2020). The Influence of Motivation and Job Satisfaction on Employee Performance in Pt. Son Karella Mare. Hasanuddin Journal of Applied Business and Entrepreneurship, 3(2), 20-32.

Putra, D. E., \& Putri, Ju. D. (2020). Effect Of Work Environment And Work Discipline On The Performance Of SPKT Unit Membersi (Integrated Police Service Center) Sungai Penuh POLSEK With Work Motivation As An Intervening Variable. Jurnal Pembangunan Berkelanjutan, 3(2), 20-26.

Ramlall, S. J. (2008). Enhancing employee performance through positive organizational behavior. Journal of Applied Social Psychology, 38(6), 1580-1600. https://doi.org/10.1111/j.1559-1816.2008.00360.x

Sakti, W. T. W., Musriha, \& Noviandari, I. (2018). Pengaruh Kepemimpinan, Disiplin Kerja dan Kompensasi terhadap Kinerja Pegawai Dinas Pertanian dan Ketahanan Pangan Provinsi Jawa Timur di Surabaya. Jurnal Manajemen Branchmarck, 4(3), 101-110.

Saleleng, M., \& Soegoto, A. S. (2015). Pengaruh lingkungan kerja, motivasi, pelatihan dan kompensasi, terhadap kinerja pegawai pada dinas pertanian Kabupaten Sorong Selatan. Jurnal EMBA: Jurnal Riset Ekonomi, Manajemen, Bisnis dan Akuntansi, 3(3), 695708.

Santoso, S., \& Tjiptono, F. (2002). Riset Pemasaran: Konsep dan. Aplikasinya dengan SPSS. Jakarta: Elex Media Komputindo.

Saunders, M., Lewis, P., \& Thornhill, A. (2011). Research Methods For Business Students, 5/e. Pearson. https://books.google.co.id/books?id=dDGPPd_4y $5 \mathrm{sC}$

Sethuraman, K., \& Suresh, J. (2014). Effective leadership styles. International Business Research, 7(9), 165. 
Sharma, M. K., \& Jain, M. S. (2013). Leadership Management: Principles, Models and Theories. Global Journal of Management and Business Studies, 3(3), 2248-9878.

Sulaeman, M. (2018). Pengaruh Motivasi dan Kepuasan Kerja terhadap Disiplin Kerja dan Dampaknya Terhadap Kinerja Pegawai Dinas Pertanian dan Ketahanan Pangan Kota Banjar. INA-Rxiv, 1-7. https://doi.org/10.31227/osf.io/8wb3a.

Syamsir, M., \& Ramlawati, R. (2019). Pengaruh Kompetensi, Motivasi, dan Kepemimpinan Terhadap Kinerja Pegawai Dinas Pertanian dan Ketahanan Pangan Kabupaten Kepulauan Selayar. MANOR: JURNAL Manajemen dan Organisasi Review, 1(2), 89_ 100.

Tandoapu, B., Syarifuddin, A., \& Buhaerah, N. (2020). Analisis Lingkungan Kerja dan Kepuasan Kerja Terhadap Kinerja Pegawai Pada Kantor Dinas Pertanian Kabupaten Morowali Utara. MM Journal, 1(2), 79-84.

Tarandung, C. D. . (2016). the Impact of Motivation, Participation and Competence of Employee Performance in Food Security and Agricultural Extension Office of East Bolaang Mongondow District. Jurnal Berkala Ilmiah Efisiensi, 16(2), 550-559.

Uzonna, R. (2013). Impact of motivation on employees performance: A case study of CreditWest Bank Cyprus. Journal of Economics and International Finance, 5(5), 199211. https://doi.org/10.5897/jeif12.086

Wahyudi, W., Semmaila, B., \& Arifin, Z. (2020). Influences of work discipline, motivation and Working Environment Non physical on Civil apparatus Performance. Point Of View Research Management, 1(3), 1-8.

Warokka, A., Gallato, C. G., Thamendren, A., \& Moorthy, L. (2012). Organizational justice in performance appraisal system and work performance: evidence from an emerging market. Journal of Human Resources Management Research, Volume 2012 (2012), Article ID 159467. DOI: $10.5171 / 2012.159467$

Wirtenberg, J., Harmon, J., Russell, W. G., \& Fairfield, K. D. (2007). HR's role in building a sustainable enterprise: Insights from some of the world's best companies. People and Strategy, 30(1), 10-20.

Wolf, L. F., \& Smith, J. K. (1995). The consequence of consequence: Motivation, anxiety, and test performance. Applied Measurement in Education, 8(3), 227-242.

Xu, G., \& Wang, Z. (2008). The impact of transformational leadership style on organizational performance: The intermediary effects of leader-member exchange. 2008 International Conference on Management Science and Engineering 15th Annual Conference Proceedings, 1090-1097. 